Khasiat Sari Buah Sirsak Gunung dan Minuman Probiotik - Fidyasari, dkk Jurnal Pangan dan Agroindustri Vol.7 No.3: 49-55, Juli 2019

\title{
KHASIAT SARI BUAH SIRSAK GUNUNG DAN MINUMAN PROBIOTIK BUAH SIRSAK GUNUNG (Annona montana) UNTUK MENURUNKAN KADAR ASAM URAT
}

\section{Therapeutic Effect of Juice and Probiotic Fruit Drink made of Sirsak Gunung (Annona Montana) on Uric Acid levels reduction}

\author{
Ambar Fidyasari' ${ }^{1}$, Muhammad Hafiz ${ }^{1}$, Nida Fitria², Ulfatur Rohmah² \\ 1) Akademi Analis Farmasi dan Makanan Putra Indonesia Malang \\ 2) Akademi Farmasi Putra Indonesia Malang \\ Jl. Barito No 5 Malang-56123 \\ Penulis Korespondensi : email: fidyafloss@gmail.com
}

\begin{abstract}
ABSTRAK
Buah sirsak gunung merupakan tanaman berkhasiat sebagai penurun kadar asam urat karena mengandung antioksidan tinggi. Buah Sirsak gunung dibuat menjadi sari buah untuk mempermudah dalam mengonsumsi dan dilanjutkan dengan difermentasi menggunakan Bakteri Lactobacillus casei. Tujuan penelitian ini untuk mengetahui khasiat sari buah sirsak gunung dan minuman probiotik buah sirsak gunung (Annona montana) pada mencit (Mus musculus L.) yang mengalami asam urat diatas normal. Penelitian ini merupakan jenis penelitian eksperimental dengan tahapan meliputi Aklimatisasi mencit 25 ekor, pemberian puree hati ayam, pembuatan minuman probiotik dan sari buah sirsak gunung, dan perlakuan uji kepada mencit selama 3 minggu. Hasil penelitian menunjukan bahwa sari buah sirsak gunung dan minuman probiotik buah sirsak gunung sama sama dapat menurunkan asam urat sebesar $50 \%$. Dari hasil penelitian ini dapat disimpulakan sari buah sirsak gunung dan minuman probiotik buah sirsak gunung memiliki aktivitas terapi pada kadar asam urat mencit.
\end{abstract}

Kata Kunci : kadar asam urat , Lactobacillus casei, Sirsak Gunung

\section{ABSTRACT}

Sirsak gunung fruit is potential as a therapeutic agent to lower uric acid levels due to its antioxidants content. Sirsak gunung fruit was processed into juice then fermented using Bacteria Lactobacillus casei. This research aimed to investigate the therapeutic effect of sirsak gunung juice and fruit probiotic (Annona montana) to in mice that emit uric acid above normal.. This research is experimental with stages including 25 mice acclimatization, Induction puree chicken's liver, making probiotic drinks and mountain soursop juice, and test treatment to mice for 3 weeks. The results showed that mountain soursop juice and mountain soursop probiotic drinks alike can reduce uric acid by $50 \%$. It was concluded that sirsak gunung juice and fruit probiotic therapeutic uric acid levels of neonatal mice.

Keywords: Lactobacillus casei, Mountain Soursop, the levels of uric acid

\section{PENDAHULUAN}

Penyakit asam urat atau biasa disebut gout merupakan penyakit metabolik yang terjadi karena kadar asam urat dalam darah melebihi batas normal, hal ini dapat diketahui karena disekitar sendi atau sistem pembuluh darah mengandung suatu endapan berupa kristal monosodium (Artini, dkk, 2012). Ciri penyakit ini biasanya disertai dengan pembengkakan, terasa nyeri dan panas diarea persendian. Faktor yang mempengaruhi kondisi ini salah satunya berasal dari hasil metabolisme asam urat yang terlalu banyak. Ketika kadar asam urat diatas nilai normal, maka dikatakan tinggi dan perlu di lakukan upaya agar segera 
diturunkan, dengan mengurangi makanan yang mengandung purin maka dapat mengurangi resiko peningkatan kadar asam urat dalam darah. (Hendriani dkk, 2016)

Alopurinol adalah Obat medis yang berfungsi untuk menurunkan kadar asam urat dalam darah. Mekanisme dari obat tersebut melalui inhibisi Xanthine oksidase menjadi Xanthine sehingga dapat menurunkan kadar asam urat dalam darah (Farid, dkk 2018). Contoh obat lain yang berfungsi menghentikan proses penyerapan kembali asam urat di ginjal adalah Probenisid (Hendriani dkk 2016). Pada umumnya penyakit asam urat dapat diturunkan dengan terapi obat dan non-obat. Terapi obat yang dilakukan dalam jangka panjang akan berakibat buruk bagi fisiologis tubuh manusia. Oleh karenanya dibutuhkan alternatif terapi non-obat untuk mencegah terjadinya efek yang merugikan tersebut, salah satu alternatif yang berpotensi adalah menggunakan minuman probiotik hasil fermentasi dari sirsak gunung (Annona montana) dan sari buah sirsak gunung yang diharapkan berfungsi sebagai terapi asam urat karena buah tersebut mengandung flavonoid yang dapat digunakan sebagai antioksidan.

Pada penelitian sebelumnya Bratasasmita (2011) menyatakan untuk menurunkan asam urat dalam darah melalui aktifitas penghabatan xantin oksidase dapat digunakan metabolit sekunder golongan flavonoida. Selain senyawa tersebut alkaloid juga dapat berfungsi dalam menghambat kerja dari Xanthine oksidase. Penelitian Prasetyorini dkk (2014) menyatakan didalam buah sirsak putih ada kandungan flavonoid, alkaloid, saponin, tanin dan polifenol yang dibuktikan dengan pengujian fitokimia secara kuantitatif. Diantara senyawa metabolit sekunder pada buah sirsak terdapat senyawa flavonoid dan polifenol yang mampu berfungsi sebagi antioksidan. Dengan daya antioksidan yang berperan sebagai penghambat Xanthine oxidase, apabila Xanthine oxidase dihambat sehingga akan mampu mengurangi kadar asam urat. Buah sirsak juga merupakan buah yang mengandung serat dan vitamin $\mathrm{C}$ yang tinggi, kandungan vitamin $C$ terdapat pada sari buah yang berkisar $38.24 \mathrm{mg} / 100 \mathrm{~g}$ daging buah. Sedangkan pada penelitian Wulandari (2017) diketahui buah sirsak gunung (Annona Montana) positif mengandung senyawa flavonoid dan polifenol dan mampu berfungsi sebagai antioksidan.

Minuman probiotik merupakan minuman yang mengandung agen probiotik. Probiotik disebut sebagai suplemen makanan berupa mikroba hidup yang memiliki kemampuan menguntungkan bagi inang yang mengkonsumsi melalui kemampuannya menjaga keseimbangan mikroba dalam saluran cerna (Sunaryanto dkk, 2014). Buah sirsak gunung (Annona Montana) ini jarang untuk dimanfaatkan sehingga buah yang sudah matang akan jatuh dan menjadi limbah. Untuk mengatasi hal tersebut maka buah sirsak gunung dimanfaatkan menjadi minuman probiotik yang harapanya nanti dapat digunakan masyarakat dalam mengatasi penyakit asam urat.

Minuman probiotik dari buah sirsak gunung (Annona Montana) dan sari buahnya diketahui mengandung senyawa flavonoid yang mampu berfungsi sebagai antioksidan. Untuk membuktikan kedua minuman ini manakah yang lebih berpotensi dalam menurunkan asam urat maka perlu dilakukan penelitian minuman probiotik dan sari buah sirsak gunung (Annona Montana) dalam menurunkan kadar asam urat.

\section{Bahan}

\section{BAHAN DAN METODE}

Bahan baku yang digunakan pada proses pembuatan sari buah dan minuman probiotik ini adalah buah sirsak gunung yang sudah matang atau umumnya sudah dapat dikonsumsi buahnya didapatkan di jalan Barito No 5 Malang. Bahan untuk membuat minuman probiotik adalah gula dan starter lactobacillus casei. Hewan percobaan mencit umur 5-6 minggu, alcohol $70 \%$, kapas, jeroan ayam, aquades.

\section{Alat}

Peralatan yang digunakan meliputi peralatan glass untuk analisis, loyang aluminium

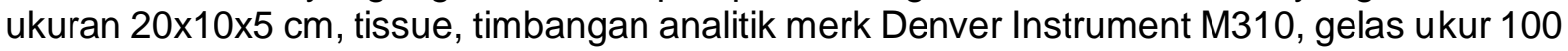
$\mathrm{ml}$, dan panci. Alat yang digunakan untuk analisis kimia meliputi gelas ukur $100 \mathrm{ml}$, tabung reaksi, erlenmeyer $250 \mathrm{ml}$ dan $500 \mathrm{ml}$, beaker glass $250 \mathrm{ml}$ dan $500 \mathrm{ml}$, labu ukur $100 \mathrm{ml}$, pipet 
volume $1 \mathrm{ml}$, bola hisap, cawan petri, cawan aluminium peralatan untuk hewan coba kandang mencit, sonde, timbangan kasar, timbangan analitik, spuit oral, pisau bedah, tes kit nesco.

\section{Desain Penelitian}

Penelitian ini merupakan penelitian eksperimental yang membandingkan 2 jenis perlakuan antara buah sirsak gunung dan minuman probiotik dari sirsak gunung tanpa ada kontrol, sehingga untuk pengujian statistik menggunakan Independent sample t-test

\section{Tahap penelitian}

Tahap penelitian meliputi:

1. Pertama dikumpulkan buah sirsak gunung yang telah berwarna kuning dan tampilan fisik baik, dibersihkan dari kotoran pada bagian luar buah sirsak kuning, dicuci buah hingga bersih dan kupas kulitnya, ditimbang sebanyak $250 \mathrm{~g}$ buah segar, dimasukan kedalam blender dan ditambahkan air sebanyak $500 \mathrm{~mL}$, dipisahkan antara sari menggunakan kain saring.

b. Kedua fermentasi buah sirsak gunung. disiapkan sari buah sisak gunung, dimasukkan dalam dalam panci kemudian dilakukan proses pasteurisasi dengan suhu $72^{\circ} \mathrm{C}$ selama 15 menit. dimasukan strain bakteri Lactobacillus casei kedalam $500 \mathrm{~mL}$ sari buah sirsak ditambah $60 \mathrm{~mL}$ strain bakteri Lactobacillus casei, terakhir dimasukkan incubator suhu $37^{\circ} \mathrm{C}$ dan lama waktu 24 jam untuk dilakukan proses inkubasi.

c. Ketiga pengujian hewan mencit jantan putih umur 3-4 bulan, berat badan 20-30 gram galur balb/c. Adaptasi selama tujuh hari diberikan pakan standar dan air minum secukupnya. Induksi jus hati ayam $8 \mathrm{~g} / \mathrm{kg}$ berat badan untuk menaikkan kadar asam urat selama 1 minggu, dan perlakuan dengan pemberian sari buah sirsak gunung $1 \mathrm{ml}$ sehari 2 kali dan kelompok kedua diberikan minuman prebiotic $1 \mathrm{ml}$ sehari 2 kali selama 1 minggu. alat pengukur kadar asam urat ( $\mathrm{Nesco} \AA)$, test strip uric acid ( $\mathrm{Nesco} \AA)$,

\section{HASIL DAN PEMBAHASAN}

\section{Hasil Uji Aktivitas Antioksidan Ekstrak Buah Sirsak Gunung (Annona montana)}

Untuk mengetahui aktivitas antioksidan dari buah sirsak gunung maka dilakukan pengujian IC 50 dengan metode DPPH. Berikut adalah hasil pengujian dengan metode DPPH dapat dilihat pada gambar 1

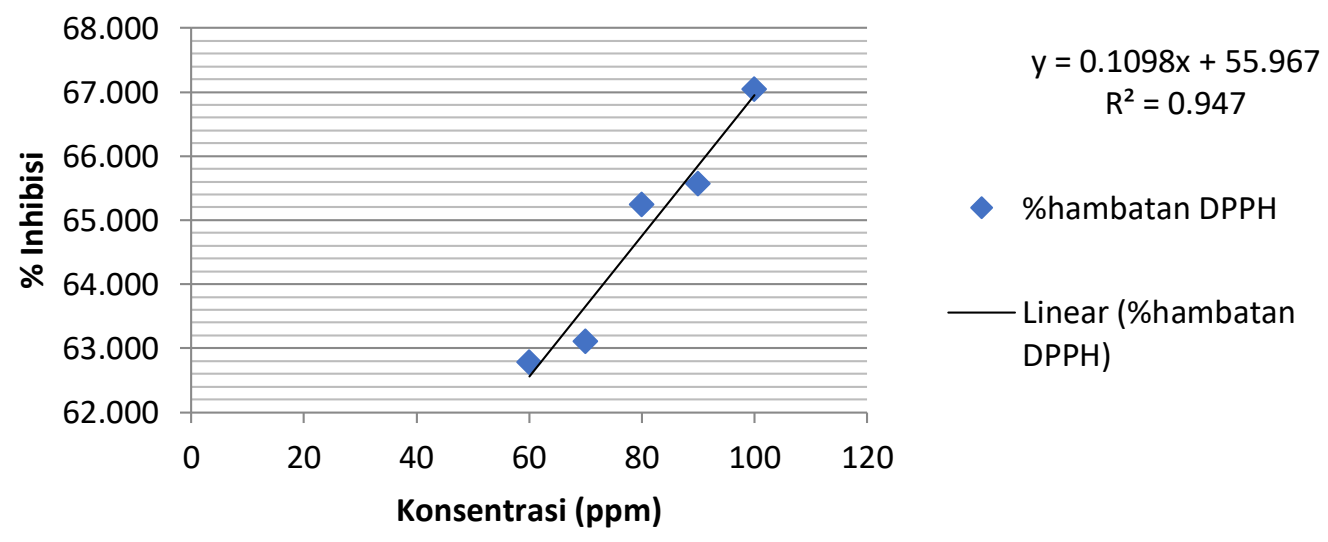

\section{Gambar 1. Kurva Linearitas Konsentrasi \% Inhibisi ekstrak buah Sirsak gunung}

Pada gambar 1 merupakan kurva linearitas dimana penentuan panjang gelombang DPPH dilakukan pada $515 \mathrm{~nm}$. Jadi, larutan blanko DPPH dan larutan sampel diukur absorbansinya dengan menggunakan panjang gelombang $515 \mathrm{~nm}$. Untuk penentuan panjang 
gelombang $515 \mathrm{~nm}$ didapatkan absorbansi DPPH sebesar $0.610 \mathrm{ppm}$. Nilai absorbansi tersebut masih dalam rentang $0.2-0.8$. Rentang serapan sinar $0.2-0.8$ dipilih sebagai batas orientasi sampel karena pada rentang tersebut data yang dihasilkan relatif linear (Emir, 2013). Menurut Molyneux 2004 bahwa warna ungu yang muncul dapat memberikan informasi terhadap radikal bebas dimana panjang gelombang $515 \mathrm{~nm}$ menunjukkan absorbansi. Ketika terjadi peningkatan kadar antioksidan dimana atom hydrogen berpasangan dengan elekton dari DPPH maka warna akan berubah dari unggu menjadi kuning. Sehingga terjadi kesetaraan antara jumlah elektron (Prakash, et al 2001). Dari hasil perhitungan persen inhibisi diatas diperoleh nilai rata-rata IC50 yaitu sebesar 61.93 ppm. Hasil tersebut dapat dikategorikan aktivitas antioksidan kuat karena nilai IC50 antara 50-100 termasuk antioksidan kuat. Nilai IC50 dapat dikategorikan menjadi 4, yaitu aktivitas antioksidan sangat kuat jika nilai IC50 < 50 , aktivitas antioksidan kuat IC50 = 50-100, aktivitas antioksidan sedang IC50 = 100-150, aktivitas antioksidan lemah IC50 $=150-200$ (Molyneux, 2004). Jadi, ekstrak buah sirsak gunung berpotensi sebagai antioksidan .

\section{Hasil Uji Aktivitas Antioksidan minuman probiotik sari buah Sirsak Gunung (Annona montana)}

Untuk mengetahui aktivitas antioksidan dari minuman prebiotik sari buah sirsak gunung maka dilakukan pengujian IC 50 dengan metode DPPH yang mana hasil dapat dilihat pada gambar berikut:

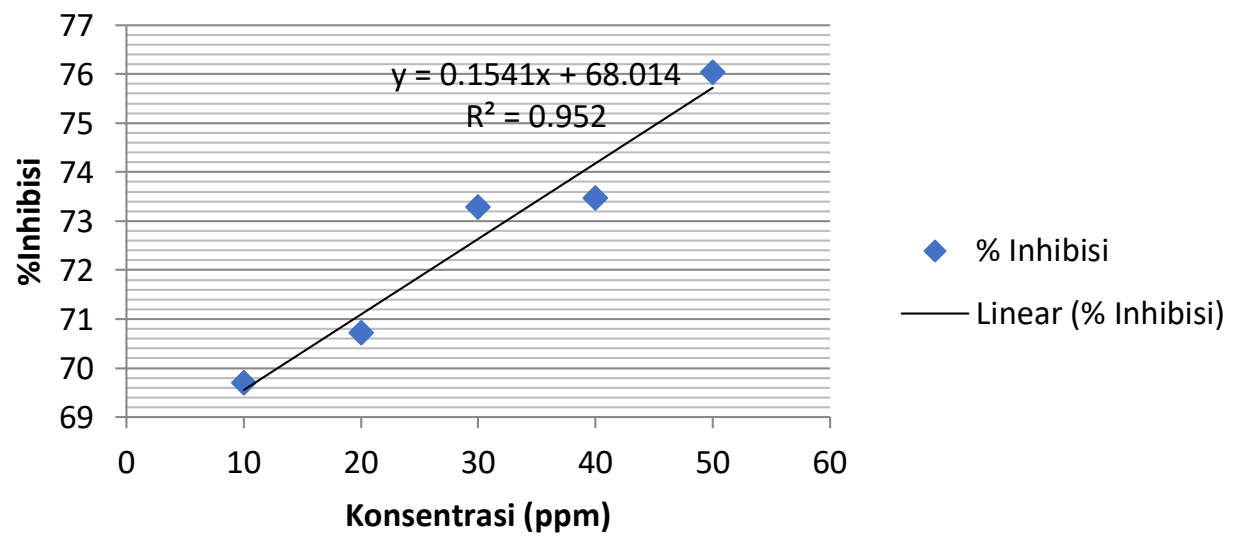

Gambar 2. Kurva Linearitas Konsentrasi \% Inhibisi minuman probiotik sari buah Sirsak gunung

Pada gambar 2 merupakan kurva linearitas dari minuman probiotik dan hasil perhitungan persen inhibisi pada gambar 2 didapatkan kosentrasi $66.43 \mathrm{ppm}$. Hal ini menujukkan sampel minuman probiotik memiliki aktivitas antioksidan meskipun melebihi dari 50\%, persen inhibisi yang baik adalah kurang $50 \%$. Adapun aktivitas antioksidan dari minuman probiotik sari buah sirsak gunung ini masuk dalam kategori antioksidan kuat. Peptida disini dihasilkan dari pemecahan protein menjadi asam asam amino yang berasal dari proses fermentasi Lactobacillus casei. Sifat antioksidan ini berasal dari degradasi protein yang menghasilkan peptide. Senyawa metabolit primer yaitu hydrogen peroksida, asam laktat dan asetat serta hasil samping berupa eksopolisakarida, senyawa yang menimbulkan bau khas dan bakteriosin dihasilkan dari proses fermentasi bakteri Lactobacillus casei (Khotimah, 2014). Molyneux 2004, adanya aktivitas antioksidan disebabkan karena jumlah total bakteri asam laktat yang meningkat dari hasil fermentasi buah, bakteri dapat mengubah struktur protein menjadi peptide sehingga hal tersebut dapat meningkatkan aktivitas antioksidannya.

\section{Asam Urat}

Pengujian yang diamati adalah penurunan kadar asam urat. Pada pengujian ini membandingkan dua kelompok perlakuan, sehingga untuk melihat data keduanya diperlukan 
analisis menggunakan uji T-test. Sari buah sirsak gunung atau minuman probiotik dari buah sirsak gunung harapannya dapat digunakan sebagai terapi antihiperurisemia bagi masyarakat.

Penelitian ini dimulai dengan melakukan perlakuan pada mencit melalui peningkatan level asam urat kemudian diukur reduksinya melalui asam urat darah mencit. Adapun Gambar 4.3 berikut menunjukkan penurunan level asam urat

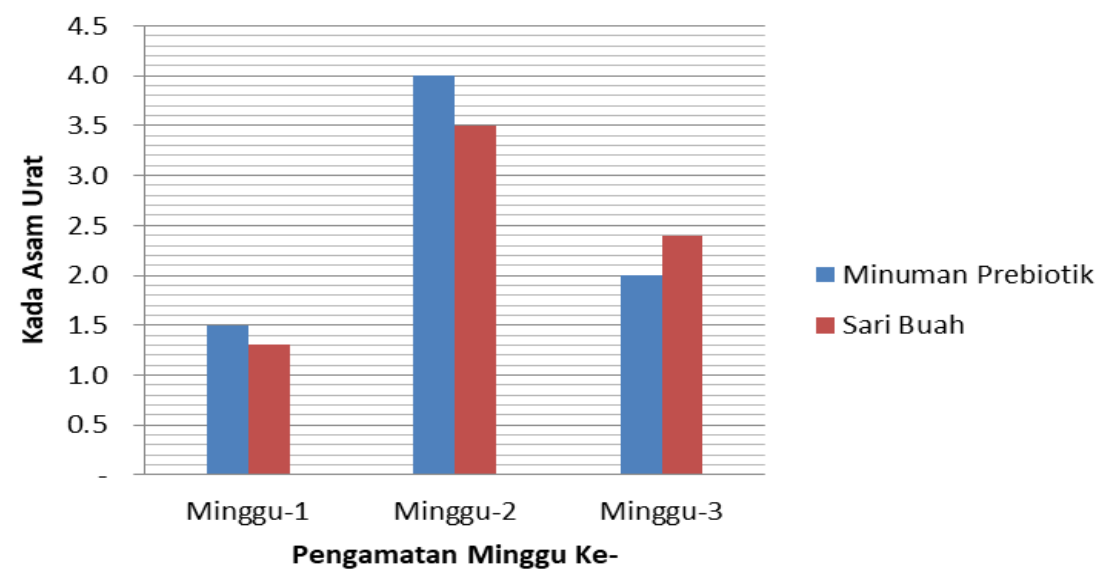

Gambar 3. Diagram penurunan level asam urat sari dan minuman probiotik buah sirsak gunung.

Gambar 3. menunjukkan perlakuan mencit yang dilakukan pada dua minggu , untuk minggu ke dua dilakukan peningkatan kadar asam urat dan minggu ketiga dilakukan kelompok perlakuan dengan pemberian sari buah dan minuman probiotik. Pada penelitian ini tidak dilakukan penggunaan kontrol, karena hanya ingin mengetahui perbandingan diantara keduanya yang paling efektif. penurunan level asam urat pada mencit dari gambar diatas berbeda antara sari buah sirsak gunung dan minuman probiotik. Untuk mengetahui perbandingan diantara keduanya maka pengolahan data menggunakan uji T-test.

Pengolahan data dengan T-test menghasilkan tidak adanya perbedaan signifikan ( $p>$ 0.05) antar perlakuan sari buah dan minuman probiotik sirsak gunung. Setelah kenaikan asam urat pada minggu ke dua dan pemberian perlakuan selama 1 minggu antara sari buah dan minuman probiotik dapat menurunkan kadar asam urat sebesar $50 \%$. Penelitian Wulandari, 2017 menunjukkan bahwa pada sari buah sirsak gunung mengandung senyawa terpenoid, yang mana golongan hidrokarbon ini biasanya ada pada bagian dari tumbuh tumbuhan. (Harborne, 1987). Senyawa fenol dapat menjadi penentu utama potensi antioksidan (Parr \& Bolwell, 2000), Menurut Farid (2018) senyawa fenol dalam tanaman memiliki aktivitas sebagai antioksidan. Aktivitas xanthine oxidase ini dapat meminimalisir terjadinya penurunan pada level asam urat disebabkan karena pada buah anonna Montana mengandung senyawa fenol. Pada penelitian ini dilakukan uji aktivitas antioksidan sari buah sirsak gunung dan memiliki IC50 yaitu sebesar 61.93 ppm. sedangkan untuk minuman probiotik sari buah sirsak gunung memiliki IC 50 sebesar 66.43 ppm. Hasil tersebut dapat digolongkan sebagai antioksidan kuat karena nilai IC50 50-100 termasuk antioksidan kuat. Nilai IC50 dapat dikategorikan menjadi 4 , yaitu aktivitas antioksidan sangat kuat jika nilai IC50 $<50$, aktivitas antioksidan kuat IC50 = 50-100, aktivitas antioksidan sedang IC50 = 100-150, aktivitas antioksidan lemah IC50 = 150200 (Molyneux, 2004). Jadi, ekstrak buah sirsak gunung berpotensi sebagai antioksidan. Hal tersebut sejalan dengan penelitian Hsieh et al., (2007), bahwa daun gandum mempunyai nilai IC50 10.89 ppm maka disimpulkan aktivitas inhibisi kuat sehingga berfungsi sebagai terapi asam urat.

Minuman probiotik dapat meningkatkan senyawa flavonoid sebagai sumber antioksidan. Bakteri asam laktat yang terkandung dalam produk minuman ini dapat memberikan aktivitas antioksidan. Dimana produk samping yang dihasilkan seperti asam asetat, asam sitrat, asam suksinat, asam malat dan asetaldehid mampu menstabilkan 
electron sehingga mempengaruhi aktivitas antioksidan. Minuman fermentasi juga dapat meningkatkan senyawa flavonoid sebagai sumber antioksidan. Aktivitas bakteri asam laktat yang ada pada produk probiotik ini dapat meningkatkan jumlah flavonoid. Lactobacillus casei mampu melepaskan gugus fenolik sehingga bersifat sebagai antioksidan. Senyawa flavonoid inilah yang bersifat sebagai antioksidan dalam tubuh. (Primurdia Dkk, 2014). Sedangkan menurut Ademiluyi (2010) produk fermentasi seperti probiotik dapat menghasilkan Eksopolisakarida (EPS) yang memiliki nilai dan kontribusi tinggi pada suatu olahan pangan sehingga mampu memberikan efek positif bagi tubuh. Efek antioksidan ini muncul berasal dari sintesis bakteri asam laktat dalam menghasilkan eksopolisakarida (EPS) yang memiliki bioaktivasi pada saluran pencernaan. Senyawa antioksidan dari minuman probiotik inilah yang memiliki aktivitas penghambat xanthine oxidase. oleh karena itu penurunan dari kedua minuman tersebut tersebut mengindikasikan bahwa aktifitas sari buah dan probiotik dapat digunakan untuk terapi antihiperurisemia.

\section{SIMPULAN}

Kesimpulan dari penelitian ini adalah sari buah sirsak gunung dan minuman probiotik buah sirsak gunung (Annona montana) keduanya sama memiliki aktivitas terhadap penurunan kadar asam urat sebesar $50 \%$.

\section{DAFTAR PUSTAKA}

Ademiluyi. 2010. Antioxidant properties of Soy-daddawa a condiment produced from fermented soybean (Glicine max (L.) Merril). Servizi Editoriali Association Srl, Via Adamo Del Pero, 6, Como, 22100. Italy.

Artini, N. P. R., Sri, W \& Wahyu, D. S. 2012. Ekstrak Daun Sirsak (Annona muricata Linn) Sebagai Antioksidan Pada Penurunan Kadar Asam Urat Tikus Wistar. Jurnal Kimia. 6 (2) : 127-137.

Bratasasmita, Ningrum. 2011. Panjang Umur dengan Sirsak dan Warisan Herbal Nusantara. Yogyakarta: Grafindo Litera Media.

Farid Wajdie, Rudi Kartika, Chairul Saleh, 2018, uji aktivitas antihiperurisemia dari ekstrak etanol daun kluwih (Artocarpus altilis (Parkinson) Fosberg) terhadap mencit jantan (Mus musculus). Jurnal Atomik., 2018, 03 (2) hal 111-115.

Harborne, J. B. 1987. Metode Fitokimia: Penuntun Cara Modern Menganalisis Tumbuhan. Institut Teknologi Bandung, Bandung. (diterjemahkan oleh Kosasih Padmawinata dan Iwang Soediro).

Hendriani, R, Elin, Y, S., Kusnandar, A \& Sukrasno. 2016. In Vitro Evaluation of Xanthine Oxidase Inhibitory Activity of Selected Medicinal Plants. International Journal of Pharmaceutical and Clinical Research. 8 (4): 235-238.

Hsieh EJ, et al. (2007) Saccharomyces cerevisiae Coq9 polypeptide is a subunit of the mitochondrial coenzyme Q biosynthetic complex. Arch Biochem Biophys 463(1):19-26

Khotimah Khusnul, Joni Kusnadi. 2014. Aktivitas Antibakteri Minuman Probiotik Sari Kurma Jurnal Pangan dan Agroindustri Vol.2 No.3 p.110-120.

Molyneux P. 2004.The Use of The Stable Free Radical Dipenylpicrylhydrazyl (DPPH) for Estimating Antioxidant Activity. Songklanakarin: Science Technology. 26 (2) : 211-219.

Parr, A. J., \& Bolwell, G.P. 2000. Phenols in the plant an in man. The potential for possible nutritional enhancement of the diet by modifying the phenols content or profile. Journal of the Science of Food and Agriculture, 80, 985-1012.

Prasetyorini dkk. 2014. Potensi Antioksidan Berbagai Sediaan Buah Sirsak (Annona muricata Linn). Bogor: Fakultas MIPA Universitas Pakuan.

Prakash, A., Rigelhof, F., and Miller, E., 2001, Antioxidant Activity: Medallion Laboratories, Analithycal Progress, 19(2), 1-4.

Primurdia, E.G. 2014. Antioxidant Activity of Probiotic Drink From Dates Extract (Phoenix dactilyfera L.) With the Isolates of $\mathrm{L}$. plantarum and L. casei. Jurnal Pangan dan Agroindustri Vol.2 No.3 p.98-109 
Sunaryanto dkk., 2014. Uji Kemampuan Lactobacillus casei Sebagai Agen Probiotik. Jurnal: http://ejurnal.bppt.go.id/index/php/JBBI

Wulandari, Septi. 2017. Senyawa metabolit sekunder dan aktivitas antioksidan pada ekstrak buah sirsak gunung (Annona montana macf. Karya Tulis Ilmiah. Akademi Farmasi Putra Indonesia Malang 